\title{
Russian Measurements
}

1 desiatin $=2.7$ acres

1 pud $=36.11$ pounds

1 ruble $=50$ U.S. cents in 1900

1 verst $=0.66$ mile 